\title{
PENGARUH PENGETAHUAN TENTANG METODE KONTRASEPSI PRIA DENGAN DUKUNGAN TERHADAP SUAMI DALAM PENGGUNAAN METODE KONTRASEPSI PRIA PADA PUS DI RT 07 RW 03 KELURAHAN NGIJO KECAMATAN GUNUNGPATI KOTA SEMARANG
}

\author{
Indah Sulistyowati, Oktaviani Cahyaningsih, dan Novita Alfiani \\ Email : indahs_17610@yahoo.com \\ Program Studi Diploma III Kebidanan STIKES Widya Husada Semarang \\ Jl. Subali Raya No. 12 Krapyak, Semarang \\ Telp (024) 7612988
}

\begin{abstract}
ABSTRAK
Kondisi lingkungan sosial, budaya, masyarakat, dan keluarga yang masih menganggap partisipasi pria belum penting dilakukan, menjadi penyebab rendahnya partisipasi pria. Masalah KB dan kesehatan reproduksi masih dipandang sebagai tanggung jawab perempuan. Pengetahuan dan kesadaran pria dan keluarga mengenai KB masih relatif rendah. Selain itu, ada keterbatasan penerimaan dan aksesabilitas pelayanan kontrasepsi pria. Peningkatan partisipasi pria diharapkan dapat meningkatkan derajat kesehatan ibu, bayi dan anak, menurunkan angka kematian ibu dan bayi, mencegah dan menanggulangi infeksi saluran reproduksi serta penyakit menular seksual, termasuk HIV/AIDS.

Dari data Profil Dinas Kesehatan Kota Semarang menunjukkan bahwa selama tahun 2014, pemakaian kontrasepsi suntik merupakan yang tertinggi karena sifatnya yang praktis dan juga cepat dalam mendapatkan pelayanannya. Apabila dibandingkan dengan data tahun 2013, kontrasepsi suntik juga masih menduduki peringkat teratas, sedangkan kontrasepsi pria merupakan yang paling sedikit digunakan yaitu kondom dan MOP. Hal ini disebabkan banyak suami masih menganggap bahwa istri saja yang mempunyai kewajiban untuk menggunakan kontrasepsi sebagai upaya pengaturan kelahiran. Tujuan penelitian ini adalah untuk mengetahui pengaruh pengetahuan tentang metode kontrasepsi pria dengan dukungan terhadap suami dalam penggunaan metode kontrasepsi pria pada PUS di RT 07 RW 03 Kelurahan Ngijo Kecamatan Gunungpati Kota Semarang.

Jenis penelitian yang digunakan adalah observasional dengan metode penelitian survei analitik yaitu survey atau penelitian yang mencoba menggali bagaimana dan mengapa fenomena kesehatan itu terjadi. Sampel dalam penelitian ini adalah semua istri pasangan usia subur yang bertempat tinggal di RT 07 RW 03 Kelurahan Ngijo Kecamatan Gunungpati Kota Semarang sejumlah 30 orang. Pada penelitian ini analisis bivariat dapat diuji menggunakan rumus Chi Square. Dari penelitian yang dilakukan didapatkan hasil, sebagian besar pengetahuan istri tentang metode kontrasepsi pria adalah kurang, sebagian besar istri tidak mendukung suami dalam penggunaan metode kontrasepsi pria dan tidak ada pengaruh pengetahuan tentang metode kontrasepsi pria dengan dukungan terhadap suami dalam penggunaan metode kontrasepsi pria pada pus di RT 07 RW 03 Kelurahan Ngijo Kecamatan Gunungpati Kota Semarang. Masyarakat diharapkan lebih aktif untuk mencari tahu serta mengakses informasi yang benar dan akurat tentang hal - hal yang berkaitan dengan penggunaan metode kontrasepsi pria termasuk efek samping dari penggunaan metode kontrasepsi pria baik kepada tenaga kesehatan, TV, media massa maupun internet.
\end{abstract}

Kata kunci : pengetahuan, dukungan, metode kontrasepsi pria

\section{Pendahuluan}

Peningkatan dan perluasan pelayanan keluarga berencana merupakan salah satu usaha untuk menurunkan angka kesakitan dan kematian ibu yang sedemikian tinggi akibat kehamilan yang dialami oleh wanita. Banyak wanita harus menentukan pilihan kontrasepsi yang sulit, karena metode metode tertentu mungkin tidak dapat diterima sehubungan dengan kebijakan nasional $\mathrm{KB}$, kesehatan individu dan seksualitas wanita atau biaya untuk memperoleh kontrasepsi. ${ }^{1}$
Dalam program KB nasional, idealnya penggunaan kontrasepsi merupakan tanggung jawab bersama pria dan wanita sebagai pasangan, sehingga metode kontrasepsi yang dipilih mencerminkan kebutuhan serta keinginan suami istri. Pasangan suami istri harus saling mendukung dalam pemilihan dan penggunaan metode kontrasepsi karena kesehatan reproduksi, khususnya keluarga berencana bukan hanya urusan pria atau wanita saja ${ }^{2}$. Namun sayangnya, peran serta pria dalam menjalankan program KB masih 
rendah. Berdasarkan data BKKBN Jawa Tengah 2009, keikutsertaan pria baru mencapai $2,33 \%$ meliputi kondom (1,5\%), dan vasektomi $(0,83 \%)$. Hal ini dapat dilihat dari berbagai aspek, yaitu dari sisi klien pria itu sendiri (pengetahuan, sikap dan praktek serta kebutuhan yang ia inginkan), faktor lingkungan yaitu sosial budaya, keterbatasan informasi dan aksesabilitas terhadap pelayanan KB pria, keterbatasan jenis kontrasepsi pria. Kecilnya angka peran serta tersebut menunjukkan kesan bahwa yang di KB-kan hanya perempuan saja.

Ketidaksetaraan gender dalam bidang KB dan kesehatan reproduksi sangat berpengaruh pada keberhasilan program. Sebagian besar masyarakat dan penyelenggara serta penentu kebijakan masih menganggap bahwa pengguna kontrasepsi adalah urusan perempuan, masih relatif rendahnya kepedulian pria dalam proses reproduksi keluarganya, terutama dalam hal kehamilan dan kelahiran. Rendahnya partisipasi pria terhadap pemakaian kontrasepsi merupakan manifestasi ketidakadilan dan ketidaksetaraan gender. ${ }^{2}$ Peserta KB di Indonesia masih didominasi oleh perempuan. Pemerintah dengan berbagai sumber daya yang telah ada berupaya untuk meningkatkan kesetaraan pria dalam ber-KB. Namun hasinya masih belum seperti yang diharapkan. Pada program KB, lebih dari 95\% peserta $\mathrm{KB}$ adalah perempuan. Hal ini sangat penting untuk diperhatikan sebab keikutsertaan pria dalam KB akan memberikan konstribusi yang sangat signifikan terhadap pengendalian pertumbuhan penduduk dan penanganan masalah kesehatan reproduksi, termasuk penanganan AKI dan AKB yang nantinya akan meningkatkan SDM Indonesia. Keterlibatan KB berwawasan gender sangat perlu sebab partisipasi pria dalam pelaksanaan program $\mathrm{KB}$ dan kesehatan reproduksi diharapkan mampu mengubah pandangan bahwa KB hanya hak dan perempuan saja, melainkan hak bersama pria dan wanita.

Di Kota Semarang pada tahun 2014, jumlah PUS yang berhasil didata oleh Puskesmas sebanyak 265.216, angka ini mengalami peningkatan jika dibandingkan dengan tahun 2013, yaitu sebanyak 163.862. Yang menjadi peserta KB baru sebanyak
36.370 orang $(13,7 \%)$ dengan jumlah peserta KB aktif yang dibina sebesar 203.328 orang $(76,7 \%)^{6}$

Dari data Profil Dinas Kesehatan Kota Semarang menunjukkan bahwa selama tahun 2014, pemakaian kontrasepsi suntik merupakan yang tertinggi karena sifatnya yang praktis dan juga cepat dalam mendapatkan pelayanannya. Apabila dibandingkan dengan data tahun 2013, kontrasepsi suntik juga masih menduduki peringkat teratas, sedangkan kontrasepsi pria merupakan yang paling sedikit digunakan yaitu kondom dan MOP. Hal ini disebabkan banyak suami masih menganggap bahwa istri saja yang mempunyai kewajiban untuk menggunakan kontrasepsi sebagai upaya pengaturan kelahiran. Angka cakupan peserta KB aktif pada tahun 2014 sebesar 76,67\% meningkat dari tahun-tahun sebelumnya yaitu pada tahun 2013 sebesar $76,46 \%$, tahun 2012 sebesar 75,03 \% dan tahun 2011 sebesar $76,02 \%$, meski pada tahun 2012 terjadi penurunan namun masih di atas target SPM yaitu $70 \%{ }^{6}$

Rendahnya peran pria dalam KB ini dipengaruhi oleh beberapa faktor, yaitu pengetahuan, akses terhadap pelayanan $\mathrm{KB}$, sosial budaya termasuk gender, dan keterbatasan alat/metode kontrasepsi untuk pria. Keterlibatan pria dalam KB dapat diwujudkan melalui perannya berupa dukungan terhadap KB dan penggunaan alat kontrasepsi serta merencanakan jumlah anak dalam keluarga. Partisipasi pria dalam KB adalah tanggung jawab pria dalam kesertaan ber-KB, serta berperilaku seksual yang sehat dan aman bagi dirinya, pasangan atau keluarganya. Dalam hal ini dinyatakan bahwa keterlibatan pria dalam program KB dapat terjadi secara langsung atau tidak langsung. Penggunaan metode kontrasepsi pria merupakan satu bentuk partisipasi pria secara langsung sedangkan keterlibatan pria secara tidak langsung misalnya pria memiliki sikap yang lebih positif dan membuat keputusan yang lebih baik berdasarkan sikap dan persepsi, serta pengetahuan yang dimilikinya. ${ }^{3,4}$

Kesertaan kaum pria sebagai peserta KB Aktif di Kota Semarang masih rendah. Rendahnya partisipasi pria dalam program KB disebabkan antara lain karena terbatasnya tempat pelayanan $\mathrm{KB}$ pria dan masih 
kurangnya tokoh $\mathrm{KB}$ pria sebagai contoh bagi masyarakat setempat. Terbatasnya metode kontrasepsi pria dalam penggunaan kondom dan Metode Operasi Pria (MOP) juga menjadi salah satu penyebab kaum pria enggan menjadi peserta aktif KB. Berdasarkan latar belakang tersebut diatas maka penulis tertarik untuk melakukan penelitian dengan mengambil judul Pengaruh Pengetahuan Tentang Metode Kontrasepsi Pria Dengan Dukungan Terhadap Suami Dalam Penggunaan Metode Kontrasepsi Pria Pada PUS Di RT 07 RW 03 Kelurahan Ngijo Kecamatan Gunungpati Kota Semarang. ${ }^{7}$

Tujuan umum penelitian ini adalah mengetahui pengaruh pengetahuan tentang metode kontrasepsi pria dengan dukungan terhadap suami dalam penggunaan metode kontrasepsi pria pada PUS di RT 07 RW 03 Kelurahan Ngijo Kecamatan Gunungpati Kota Semarang. Sedangkan tujuan khusus penelitian ini adalah mengetahui gambaran pengetahuan tentang metode kontrasepsi pria pada PUS di RT 07 RW 03 Kelurahan Ngijo Kecamatan Gunungpati Kota Semarang, mengetahui gambaran dukungan terhadap suami dalam penggunaan metode kontrasepsi pria pada PUS di RT 07 RW 03 Kelurahan Ngijo Kecamatan Gunungpati Kota Semarang, dan menganalisis pengaruh pengetahuan tentang metode kontrasepsi pria dengan dukungan terhadap suami dalam penggunaan metode kontrasepsi pria pada PUS di RT 07 RW 03 Kelurahan Ngijo Kecamatan Gunungpati Kota Semarang

\section{Metode Penelitian}

Jenis penelitian yang digunakan adalah observasional dengan metode penelitian survei analitik kemudian melakukan analisis dinamika korelasi antara fenomena, baik antara faktor risiko dengan faktor efek, antar faktor risiko, maupun antar faktor efek, dimana peneliti hanya melakukan observasi tanpa memberikan intervensi pada variabel yang diteliti dengan pendekatan yang digunakan adalah Pendekatan Cross Sectional dimana cara pengambilan data variabel bebas dan variabel terikat dilakukan sekali waktu pada saat yang bersamaan.,

Populasi dalam penelitian ini adalah semua istri pasangan usia subur yang bertempat tinggal di RT $07 \quad$ RW 03 Kelurahan Ngijo Kecamatan Gunungpati
Kota Semarang dengan jumlah 30 orang istri pasangan usia subur. Sampel dalam penelitian ini adalah semua istri pasangan usia subur yang bertempat tinggal di RT 07 RW 03 Kelurahan Ngijo Kecamatan Gunungpati Kota Semarang sejumlah 30 orang dengan teknik sampling yang digunakan adalah teknik sampling jenuh, yaitu teknik menentukan sampel bila semua anggota populasi digunakan sebagai sampel. Hal ini sering dilakukan jika jumlah populasi relatif kecil yakni kurang dari 30 orang.

Variabel dalam penelitian ini adalah Pengetahuan Istri Tentang Metode Kontrasepsi Pria dan Dukungan Istri Terhadap Suami Dalam Penggunaan Metode Kontrasepsi Pria, variabel tersebut didefinisikan dan diukur dengan cara sebagai berikut. Pengetahuan istri tentang metode kontrasepsi pria yaitu sejauh mana istri mengetahui dan memahami tentang metode kontrasepsi kondom dan vasektomi.. Untuk mengukur hal tersebut digunakan kuesioner, untuk variabel Pengetahuan istri tentang metode kontrasepsi pria dengan jumlah pertanyaan 15 soal. Pernyataan positif, skor 1 (satu) untuk jawaban benar, skor 0 (nol) untuk jawaban salah. Pernyataan negatif, skor 0 (nol) untuk jawaban benar, skor 1 (satu) untuk jawaban salah. Skala yang digunakan adalah skala ordinal. Dukungan Istri Terhadap Suami Dalam Penggunaan Metode Kontrasepsi Pria adalah Reaksi atau respon istri terhadap suami dalam penggunaan metode kontrasepsi pria, dikategorikan menjadi dua, yaitu Tidak Mendukung dan Mendukung.

Dalam penelitian ini, data primer diperoleh secara langsung dari responden dengan menggunakan kuesioner yang berisi pertanyaan pengetahuan tentang metode kontrasepsi pria dan dukungan istri terhadap suami dalam penggunaan metode kontrasepsi pria. Data sekunder pada penelitian ini diperoleh dari Dinas Kesehatan Kota Semarang berupa data jumlah pasangan usia subur dan data akseptor KB. ${ }^{7}$

Pada penelitian ini analisis univariate dilakukan pada variabel pengetahuan tentang metode kontrasepsi pria dan dukungan istri terhadap suami dalam penggunaan metode kontrasepsi pria. Dalam analisis ini hanya menghasilkan distribusi dan persentase dari tiap variabel. Hasil persentase dari tiap 
variabel tersebut disusun dalam bentuk tabel univariat yaitu suatu tabel yang menggambarkan penyajian data untuk tiap variabel saja. Selain itu juga dilakukan analisis bivariat yang dilakukan pada dua variabel yang diduga berhubungan atau korelasi. Dalam penelitian ini variabel yang dihubungkan adalah Pengetahuan Istri Tentang Metode Kontrasepsi Pria terhadap Dukungan Istri dengan Suami Dalam Penggunaan Metode Kontrasepsi Pria. Karena data yang diolah berupa data ordinal dan nominal, maka analisis data ini dapat diuji menggunakan Chi Square, yaitu teknik statistik yang digunakan untuk menguji hipotesis bila dalam populasi terdiri atas dua atau lebih kelas dimana data berbentuk nominal dan sampelnya besar. ${ }^{8,9}$

\section{Hasil dan Pembahasan}

Hasil penelitian pada analisis univariat disajikan dalam bentuk tabel distribusi frekuensi, sebagaimana diuraikan secara ringkas di bawah ini. Tabel 1 menyajikan data tentang Pengetahuan Istri Tentang Metode Kontrasepsi Pria, sementara Tabel 2 menyajikan data tentang Dukungan Istri Terhadap Suami Dalam Penggunaan Metode Kontrasepsi Pria.

Tabel 1

Distribusi Frekuensi Responden Berdasarkan Pengetahuan Istri Tentang Metode Kontrasepsi Pria

\begin{tabular}{lll}
\hline Pengetahuan & Frekuensi & Persentase \\
\hline Kurang & 16 & $53.3 \%$ \\
Baik & 14 & $46.7 \%$ \\
\hline Jumlah & 30 & 100 \\
\hline
\end{tabular}

Dari Tabel 1 menunjukkan bahwa sebagian besar istri kurang mengetahui tentang metode kontrasepsi pria yaitu sebanyak 16 orang $(53.3 \%)$.

Tabel 2

Distribusi Frekuensi Responden Berdasarkan

Dukungan Istri Terhadap Suami Dalam Penggunaan Metode Kontrasepsi Pria

\begin{tabular}{lll}
\hline Perilaku & Frekuensi & Persentase \\
\hline $\begin{array}{l}\text { Tidak } \\
\text { Mendukung }\end{array}$ & 27 & $90.0 \%$
\end{tabular}

\begin{tabular}{lll} 
Mendukung & 3 & $10.0 \%$ \\
\hline Jumlah & 30 & 100 \\
\hline
\end{tabular}

Dari Tabel 2 menunjukkan bahwa sebagian besar istri tidak mendukung suami dalam penggunaan metode kontrasepsi pria yaitu sebanyak 27 orang $(90.0 \%)$..

Hasil penelitian pada analisis bivariat diuraikan secara ringkas di bawah ini. Tabel 3 menyajikan data tentang Pengaruh Pengetahuan Istri Tentang Metode Kontrasepsi Pria dengan Dukungan Istri dengan Suami Dalam Penggunaan Metode Kontrasepsi Pria.

Tabel 3

Pengaruh Pengetahuan Istri Tentang Metode Kontrasepsi Pria dengan Dukungan Istri dengan Suami Dalam Penggunaan Metode Kontrasepsi Pria

\begin{tabular}{lllllll}
\hline \multirow{2}{*}{$\begin{array}{l}\text { Pengetahu } \\
\text { an }\end{array}$} & \multicolumn{2}{l}{ Dukungan } & \multicolumn{3}{l}{ Jumlah } \\
\cline { 2 - 5 } & \multicolumn{2}{l}{ Tidak } & \multicolumn{2}{c}{ Ya } & & \\
\cline { 2 - 5 } & $\mathrm{f}$ & $\%$ & $\mathrm{f}$ & $\%$ & $\mathrm{f}$ & $\%$ \\
\hline Kurang & 16 & $100 \%$ & 0 & $0 \%$ & 16 & $100 \%$ \\
Baik & 11 & $78.6 \%$ & 3 & $21.4 \%$ & 14 & $100 \%$ \\
\hline Jumlah & 27 & $90 \%$ & 3 & $38.1 \%$ & 30 & $100 \%$ \\
\hline
\end{tabular}

Dari hasil analisa data dengan menggunakan uji statistik Chi Square mengenai pengaruh pengetahuan tentang metode kontrasepsi pria dengan dukungan terhadap suami dalam penggunaan metode kontrasepsi pria diperoleh nilai $\rho$ value $=$ $0,090>0,05$. maka dikatakan Ha ditolak yang artinya tidak ada pengaruh pengetahuan tentang metode kontrasepsi pria dengan dukungan terhadap suami dalam penggunaan metode kontrasepsi pria pada pus di RT 07 RW 03 Kelurahan Ngijo Kecamatan Gunungpati Kota Semarang.

Dukungan adalah suatu upaya yang diberikan kepada orang lain, baik moril maupun materil untuk memotivasi orang tersebut dalam melakukan kegiatan. Caplan dalam Friedman (1998) menjelaskan bahwa keluarga memiliki beberapa fungsi dukungan, yaitu: (1) Dukungan instrumental; (2) Dukungan informatif; (3) Dukungan emosional; dan (4) Dukungan penghargaan

Salah satu bentuk dukungan instrumental yaitu berupa penyediaan materi yang dapat memberikan pertolongan langsung seperti pinjaman uang, pemberian barang, makanan serta pelayanan. Bentuk 
dukungan ini dapat mengurangi kecemasan karena individu dapat langsung memecahkan masalahnya yang berhubungan dengan materi. Dukungan instrumental sangat diperlukan dalam mengatasi masalah yang dianggap dapat dikontrol. Dalam penggunaan metode kontrasepsi salah satu bentuk dukungan instrumental adalah dengan memberikan bantuan biaya untuk penggunaan metode kontrasepsi oleh pasangannya. Biaya juga merupakan salah satu faktor yang mempengaruhi akseptor dalam penggunaan metode kontrasepsi. Sehingga idealnya dalam penggunaan metode kontrasepsi perlu adanya dukungan biaya dari pasangannya. ${ }^{10}$

Dalam hal ini apabila seorang istri mempunyai pengetahuan yang baik tentang metode kontrasepsi pria tentunya akan memberikan dukungan terhadap suami dalam penggunaan metode kontrasepsi pria salah satunya dalam bentuk dukungan informasional yaitu bentuk dukungan yang melibatkan pemberian informasi, pengetahuan, petunjuk, saran atau umpan balik tentang situasi dan kondisi individu. Jenis informasi seperti ini dapat menolong individu untuk mengenali dan mengatasi masalah dengan lebih mudah seperti memberikan informasi dan saran tentang pilihan metode kontrasepsi yang dapat digunakan oleh suami. ${ }^{11}$

\section{Kesimpulan}

Dari penelitian yang sudah dilakukan dapat disimpulkan bahwa sebagian besar pengetahuan istri tentang metode kontrasepsi pria adalah kurang, sebagian besar istri tidak mendukung suami dalam penggunaan metode kontrasepsi pria dan tidak ada pengaruh pengetahuan tentang metode kontrasepsi pria dengan dukungan terhadap suami dalam penggunaan metode kontrasepsi pria pada pus di RT 07 RW 03 Kelurahan Ngijo Kecamatan Gunungpati Kota Semarang.

\section{Daftar Pustaka}
[1] Depkes, 2002
Penetapan
Petunjuk Pelaksanaan Indikator Menuju Indonesia Sehat 2010. Depkes RI. Jakarta.

[2] BKKBN. 2007. Keluarga Berencana Dan Kontrasepsi Cetakan Ke-5. Pustaka Sinar Harapan. Jakarta.

[3] BKKBN. 2003. Peningkatan Partisipasi Pria Dalam Keluarga Berencana dan Kesehatan Reproduksi. Jakarta

[4] Saifudin, Abdul Bahri. 2002. Buku Panduan Praktis Pelayanan Kesehatan Maternal Neonatal. JHPIEGO. Jakarta

[5] BKKBN. 2011. Laporan Umpan Balik Hasil Pelaksanaan Program KB Nasional Provinsi Jawa Tengah.

[6] Profil Dinas Kesehatan Provinsi Jawa Tengah. 2010.

[7] Profil Dinas Kesehatan Kabupaten Kendal. 2013.

[8] Friedman, Marilyn M. 2010. Buku Ajar Keperawatan Keluarga : Riset, Teori Dan Praktek. EGC. Jakarta.

[9] Notoatmodjo, Soekidjo. 2005. Metodologi Penelitian Kesehatan (edisi revisi). Rineka Cipta. Jakarta.

[10] Manuaba, Ida Bagus Gde. 2002. Ilmu Kebidanan Penyakit Kandungan Dan Keluarga Berencana Untuk Pendidikan Bidan. Jakarta : EGC.

[11] Hartanto, Hanafi. 2004. Keluarga Berencana dan Kontrasepsi. Pustaka Sinar Harapan. Jakarta. 